\title{
Postglacial Isostatic Movement in Northeastern Devon Island: A Reappraisal
}

\author{
WILLIAM BARR ${ }^{1}$
}

\begin{abstract}
Amended emergence and uplift curves are presented for the Truelove Inlet area. The new curves are based mainly on radiocarbon dates from whalebone, driftwood and basal peat. The marine limit lies at $76 \mathrm{~m} . a . s .1$. , and dates to approximately 9,450 B.P., which is also considered to be the date of deglaciation; total postglacial uplift is $107 \mathrm{~m}$. The rate of uplift during the first thousand years following deglaciation reached $4.05 \mathrm{~m}$. per century, which is markedly less rapid than was previously reported. The rate of uplift decreased steadily thereafter and, at present, appears to be matched by eustatic sea level rise.

What had appeared to be fossil evidence of restrained rebound at the onset of uplift, was probably due to accidental mixing during collection of interstadial shells with postglacial shells. The total amount of postglacial uplift, and the rates of uplift, have probably been somewhat suppressed by the close proximity of the Devon Island Ice Cap.
\end{abstract}

RÉSUMÉ. Réévaluation du mouvement isostatique postglaciaire dans le nord-est de l'île Devon. L'auteur présente des courbes corrigées d'émergence et de relèvement pour la région de Truelove Inlet. Ces nouvelles courbes sont surtout basées sur des radiodatations d'os de baleines, de bois flotté et de tourbe profonde. La limite marine se trouve à $76 \mathrm{~m}$ au dessus du niveau de la mer et remonte approximativement à 9450 A.P., ce qui est aussi considéré comme la date de la déglaciation; l'émergence postglaciaire totale est de $107 \mathrm{~m}$. Au cours du premier millénaire après la déglaciation, le taux d'émergence a atteint $4,05 \mathrm{~m} /$ siècle, ce qui est beaucoup moins rapide que ce que l'on avait d'abord rapporté. Ce taux a régulièrement décru par la suite et, à présent, semble compensé par le relèvement eustatique du niveau de la mer.

Ce qui semblait une preuve fossile d'un rebondissement retenu au début de l'émergence était probablement dû à un mélange accidentel de coquillages interstadiaires et poststadiaires au cours de lacteillette. L'émergence postglaciaire totale et les taux d'émergence ont probablement été quelque peu amortis par la proximité de la calotte glaciaire de l'île Devon.

РЕЗЮМЕ. Послеледниковал изостатическая компенсачил в северо-восточной части о-ва Девон. Пересматриваются результаты предыдущих исследований послеледниковой изостатической компенсации в районе Трюлав Инлет на о-ве Девон. Приводятся уточненные данные по поднятию суши, основанные на датировке радиоутлеродным методом китовых усов, обломков древесины и торфа.

\section{INTRODUCTION}

In 1966, a paper was published in this journal, in which a preliminary study of the postglacial uplift of the lowland adjoining Truelove Inlet on the north coast of Devon Island (Fig. 1) was presented (Müller and Barr 1966). After completion of more detailed fieldwork, and the accumulation of many more radiocarbon

1Department of Geography, University of Saskatchewan, Saskatoon, Canada. 


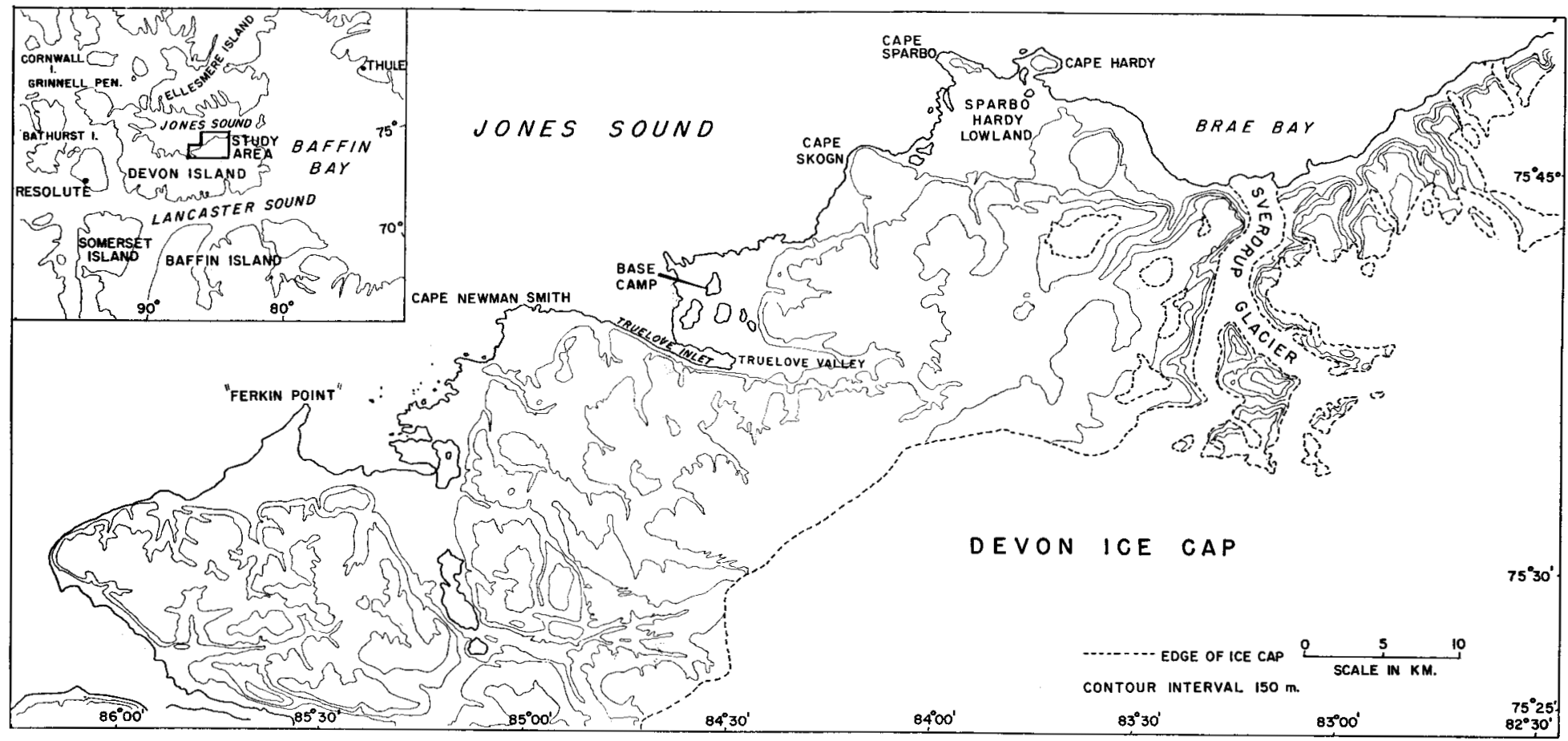

FIG. 1. Location of the field area, Devon Island, N.W.T. 
dates of organic material pertaining to the position of former sea levels, it is felt that a fuller discussion of the postglacial uplift of the area should now be presented. It is hoped that the results presented here will in part answer Andrews' plea (1970b, p. 149) for detailed curves of postglacial uplift from the Queen Elizabeth Islands. As a result of the new evidence, the shape of the uplift curve has been considerably modified, and the hypothesis of restrained rebound at the onset of uplift, based on fossil finds, has been discarded. Evidence of an interstadial in the form of marine molluscs dating to $>30,000$ B.P., was discovered.

\section{PHYSIOGRAPHY}

The details of the physiography of the area around Truelove Inlet were discussed in the earlier paper, but the major points bear reiteration here. An interior plateau (Fig. 2), at an elevation of 300 to $800 \mathrm{~m}$. is separated from an intermittent coastal lowland by a series of bold escarpments. The entire coastal lowland area was submerged during the postglacial transgression; the marine limit lies at $76 \mathrm{~m}$. in the Truelove Inlet area. This lowland area, the site of the Arctic Institute of North America's Base Camp, is characterized by a flight of raised beach ridges and terraces, which originally developed as off-shore bars on this gently sloping shore-line. The bars have successively emerged during the course of uplift to produce the striking pattern of raised beach ridges and terraces now so conspicuous in the landscape (Fig. 3). The beach ridges and the intervening areas contain large numbers of fossil marine molluscs although, as will become apparent in the discussion, these are not necessarily in situ.

\section{FIELD PROCEDURES}

The earlier uplift curve was based entirely on radiocarbon dates of fossil marine molluscs, collected from the surface. While it was recognized that the relative unreliability of marine mollusc dates derives from an uncritical use of such dates, fieldwork during the 1966 and 1967 seasons was concentrated on the collection of other types of organic material, which might be considered to offer a greater degree of reliability with respect to radiocarbon dating of former sea levels. These materials included whalebone and driftwood. Some marine molluses and samples of basal peat were also collected (Table 1 and Fig. 2).

The whalebone material was collected from skulls of the Greenland whale (Balaena mysticetus; identified from a photograph by R. Lawes), embedded in the sand and gravel of the raised beaches. The upper surface of the whalebone is commonly level with the ground surface, and the skulls can be detected from a distance only by the slightly more luxuriant vegetation (Fig. 4) associated with the whalebone.

It is believed that the whale skulls attained their present positions as the result of natural strandings of whales on the gently shelving beaches. This is a reasonably common phenomenon at present (Ray 1961; Dudok Van Heel 1962, 1966). As Dudok Van Heel has pointed out, mass strandings of whales occur most frequently on gently sloping sandy or muddy beaches similar to those in the field area, from 


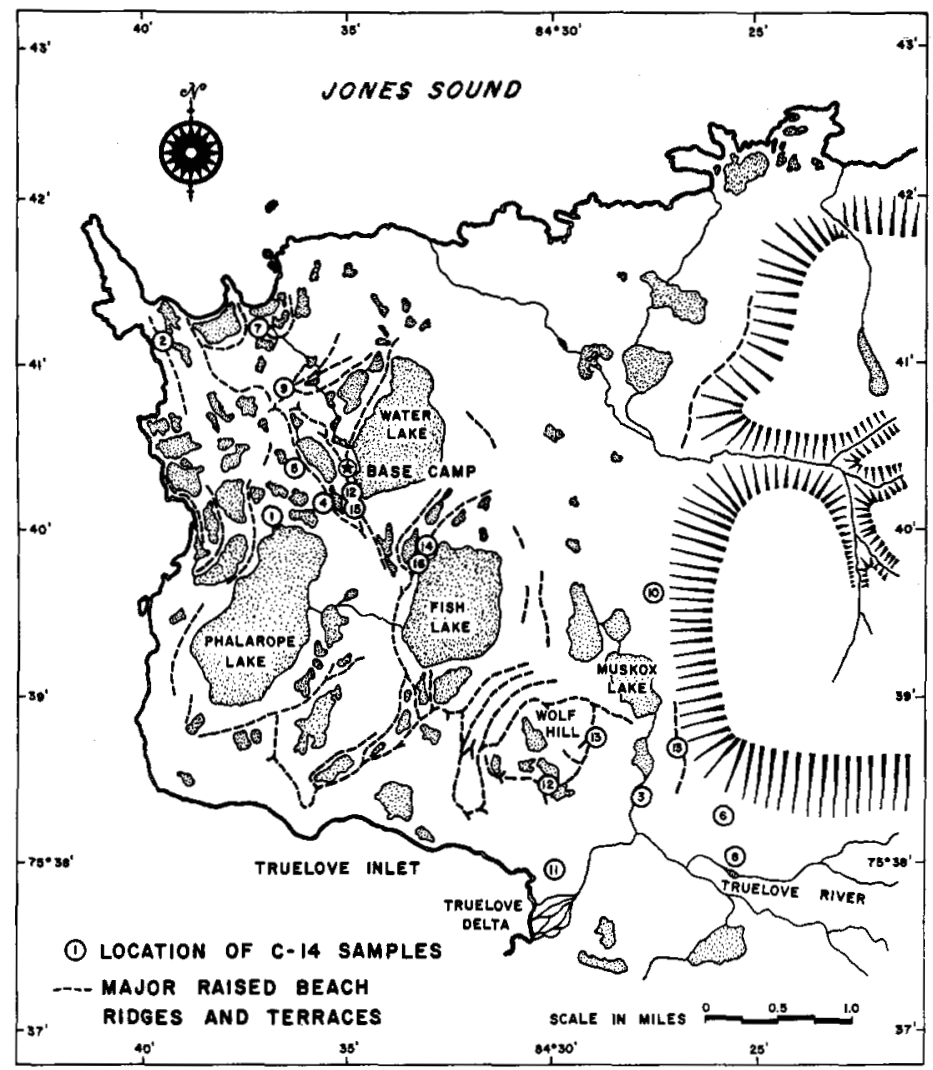

FIG. 2. Truelove Inlet area, showing locations of $14 \mathrm{C}$ dated samples. Numbers refer to Table 1.

which the whales, using their "sonar" (echo-sounding by means of ultrahighfrequency vibrations), are unable to obtain a good echo. The other parts of the whales' skeletons tend to disintegrate relatively rapidly; large numbers of ribs and vertebrae are found at low elevations near "Ferkin Point" and elsewhere, but only the more massive skulls were found at higher elevations. Possibly, also, their larger size makes them more easily visible.

The collecting of samples from the skulls was quite selective. Since much of the bone is fibrous, and contains a high percentage of air-filled voids, the problem of penetration by vegetation rootlets, with resultant contamination of the sample is acute. Hence, as far as possible, only dense, solid bone was collected. It was found that the ear-bones best meet this requirement, being of a very dense, ivorylike material. Collection of samples from the area of the ear usually involved some vigorous axe-work (Fig. 4).

It is felt that while the whalebone may in some cases have been deposited in deep water, it generally provides a more reliable indicator of contemporary sea level than do marine shells. Similarly, the possibility of movement by glacier ice cannot be entirely ruled out, but from the dates obtained, such transport does not seem to have occurred.

Driftwood is equally useful as an indicator of former sea levels. However, due 
TABLE 1. Details of radiocarbon dates of organic material from area around Truelove Inlet

\begin{tabular}{|c|c|c|c|c|c|}
\hline $\begin{array}{l}\text { Sample } \\
\text { number }\end{array}$ & $\begin{array}{l}\text { Lab. } \\
\text { number }\end{array}$ & $\begin{array}{l}\text { Locality } \\
\text { and } \\
\text { Material }\end{array}$ & $\begin{array}{c}\text { Field } \\
\text { elevation } \\
\text { (m.a.s.l.) }\end{array}$ & $\begin{array}{l}\text { Uplift m. } \\
\text { (corrected } \\
\text { for sea } \\
\text { level rise) }\end{array}$ & $\begin{array}{c}\text { Age } \\
\text { (radiocarbon } \\
\text { years) }\end{array}$ \\
\hline 1 & I-3231 & $\begin{array}{l}\text { Basal peat sample from peat bog, } 1 \mathrm{~km} \text {. } \\
\text { SW of Base Camp }\end{array}$ & 3.6 & 5.5 & $2,450 \pm 90$ \\
\hline 2 & S-433 & $\begin{array}{l}\text { Whalebone; ear bone and other dense } \\
\text { parts; from skull embedded in lowest } \\
\text { raised beach; } 2.4 \mathrm{~km} \text {. NW of Base Camp. }\end{array}$ & 3.0 & 4.2 & $2,900 \pm 85$ \\
\hline 3 & $S-430$ & $\begin{array}{l}\text { Basal peat sample from peat bog cut by } \\
\text { stream, } 0.8 \mathrm{~km} \text {. S of Muskox Lake. }\end{array}$ & 26.0 & 29.5 & $4,300 \pm 95$ \\
\hline 4 & $S-431$ & $\begin{array}{l}\text { Driftwood embedded in beach gravels } \\
\text { beneath frozen peat; seaward side of } \\
\text { raised beach ridge; } 0.4 \mathrm{~km} \text {. SSW of } \\
\text { Base Camp. }\end{array}$ & 11.0 & 16.0 & $5,280 \pm 100$ \\
\hline 5 & S-432 & $\begin{array}{l}\text { Whalebone embedded in limestone } \\
\text { beach rubble, seaward side of raised } \\
\text { beach ridge, } 0.4 \mathrm{~km} \text {. W of Base Camp. }\end{array}$ & 11.0 & 18.0 & $6,100 \pm 125$ \\
\hline 6 & $\mathrm{~S}-428$ & $\begin{array}{l}\text { Basal peat from peat hummocks, N. side } \\
\text { of Truelove Valley. }\end{array}$ & 57.0 & 65.0 & $6,900 \pm 115$ \\
\hline 7 & Y-1294 & $\begin{array}{l}\text { Marine shells, mostly Hiatella arctica } \\
\text { from fine centres of patterned ground; } \\
\text { "Meat Cache" beach; } 1.6 \mathrm{~km} \text {. NW of } \\
\text { Base Camp. }\end{array}$ & 3.4 & 17.0 & $7,480 \pm 120$ \\
\hline 8 & S-434 & $\begin{array}{l}\text { Marine shells; Mya truncata and } \\
\text { Hiatella arctica; embedded in surface of } \\
\text { yellow silt, Truelove Valley. }\end{array}$ & 30.0 & 49.8 & $8,200 \pm 140$ \\
\hline 9 & $Y-1295$ & $\begin{array}{l}\text { Marine shells; Mya truncata and } \\
\text { Hiatella arctica; surface of "Whalebone } \\
\text { beach", } 1.3 \mathrm{~km} \text {. NW of Base Camp. }\end{array}$ & 7.7 & 27.7 & $8,250 \pm 160$ \\
\hline 10 & GSC-991 & $\begin{array}{l}\text { Whalebone; skull embedded in yellow } \\
\text { silt at foot of escarpment, } 3.6 \mathrm{~km} \text {. ESE } \\
\text { of Base Camp. }\end{array}$ & 42.4 & 62.5 & $8,270 \pm 150$ \\
\hline 11 & S-410 & $\begin{array}{l}\text { Marine shells from solifluction lobe near } \\
\text { Truelove Delta. }\end{array}$ & 25.0 & 42.0 & $8,370 \pm 115$ \\
\hline 12 & Y-1296 & $\begin{array}{l}\text { Marine shells, mainly Hiatella arctica; } \\
\text { surface of Base Camp beach, imme- } \\
\text { diately } \mathrm{S} \text { of Base Camp. }\end{array}$ & 15.5 & 40.2 & $8,740 \pm 120$ \\
\hline 13 & $Y-1299$ & $\begin{array}{l}\text { Marine shells from two spots at same } \\
\text { altitude: 1) terrace on SE side of Wolf } \\
\text { Hill; 2) well-developed beach } E \text { of Wolf } \\
\text { Hill at foot of escarpment. }\end{array}$ & 60.0 & 86.1 & $9,360 \pm 160$ \\
\hline 14 & $S-413$ & $\begin{array}{l}\text { Marine shells (mainly Hiatella arctica) } \\
\text { from surface of Fish Lake raised beach. }\end{array}$ & 23.0 & & $9,570 \pm 130$ \\
\hline 15 & $S-412$ & $\begin{array}{l}\text { Marine shells (mainly Hiatella arctica) } \\
\text { from Base Camp raised beach. }\end{array}$ & 15.5 & & $12,800 \pm 160$ \\
\hline 16 & $Y-1297$ & $\begin{array}{l}\text { Marine shells from surface of Fish Lake } \\
\text { raised beach. }\end{array}$ & 23.0 & & $16,000 \pm 240$ \\
\hline 17 & $Y-1733$ & $\begin{array}{l}\text { Marine shells from raised beach on } \mathrm{S} \\
\text { side of Wolf Hill. }\end{array}$ & 36.0 & & $30,100 \pm 1500$ \\
\hline 18 & Y-1734 & $\begin{array}{l}\text { Marine shells from lowland } S \text { of Cape } \\
\text { Skogn; } N \text { side of } 2 \text { nd major river } S \text { of } \\
\text { the cape; from surface of frost boils. }\end{array}$ & 27.0 & & $31,200 \pm 1800$ \\
\hline
\end{tabular}




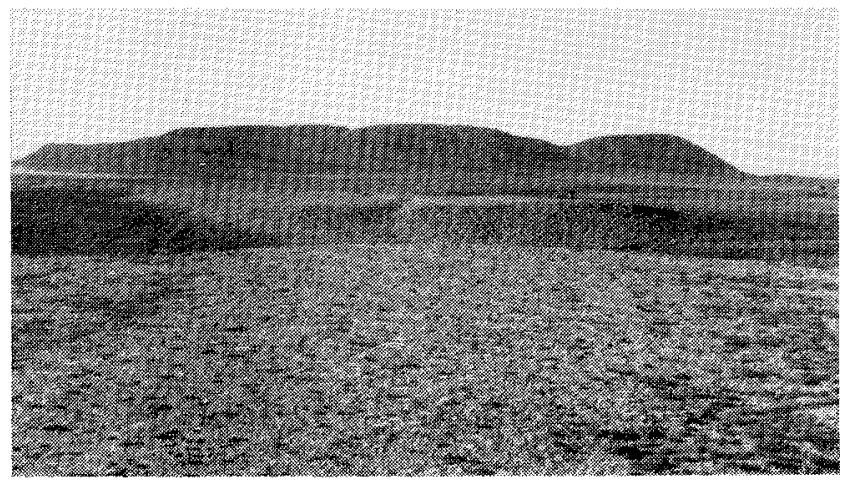

FIG. 3. Typical raised beach ridge, south of Cape Sparbo. The gap through the ridge developed as the entrance to a tidal lagoon. Sea is to the left.

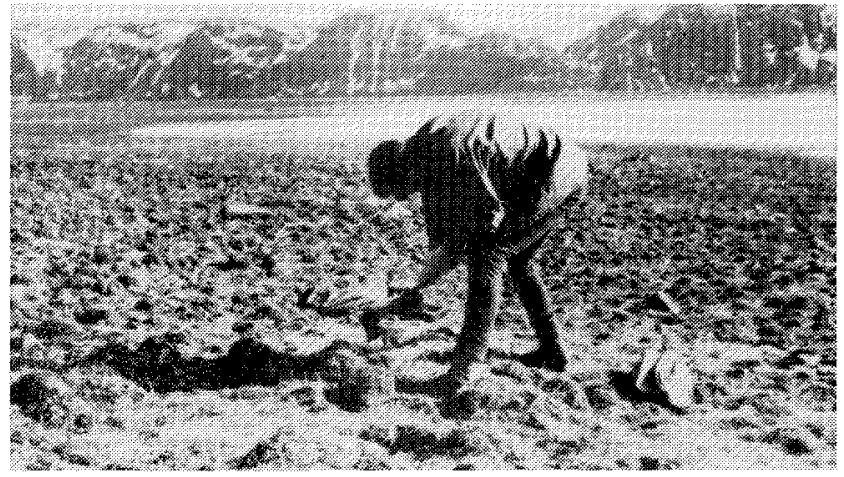

FIG. 4. Collecting a sample of whalebone for ${ }^{14} \mathrm{C}$ dating. The whale skull is embedded in the raised beach, and is practically invisible from a distance.

to the location of Jones Sound with respect to the pattern of ocean currents, driftwood is relatively scarce, even on the present beach. This makes the finding of one sample of driftwood $(\mathrm{S}-431 ; 11 \mathrm{~m}$.) all the more valuable. This sample had been preserved in frozen peat on the seaward side of a raised beach ridge. Although severely split and shattered by frost action, the wood was in good condition, and relatively uncontaminated by plant rootlets. The wood has been identified by $\mathbf{R}$. J. Mott as Picea or Larix, probably the latter. Unfortunately, no pumice such as was used by Blake $(1961,1970)$ in his studies of the raised beaches of Svalbard, and on the north shore of Jones Sound, was encountered in the field area.

To obtain further datable material which might assist in determining former sea level positions, cores were extracted from several peat-bogs in the Base Camp lowland. As the active layer in peat is very shallow, most of the coring was in frozen peat, and an ice-corer was used. On the assumption that organic material did not begin to accumulate until after emergence of the site from the sea, the basal peat deposits should provide a minimum age for the emergence of any particular location.

In many places, peat accumulation may not have begun for hundreds, or even thousands of years after emergence. This appears to have been the case in samples S-428 and S-430 (Fig. 5) both collected from high-level peat deposits. Of course the possibility of contamination should not be ruled out entirely. In view of this, sample I-3231, where the onset of peat accumulation almost immediately after 


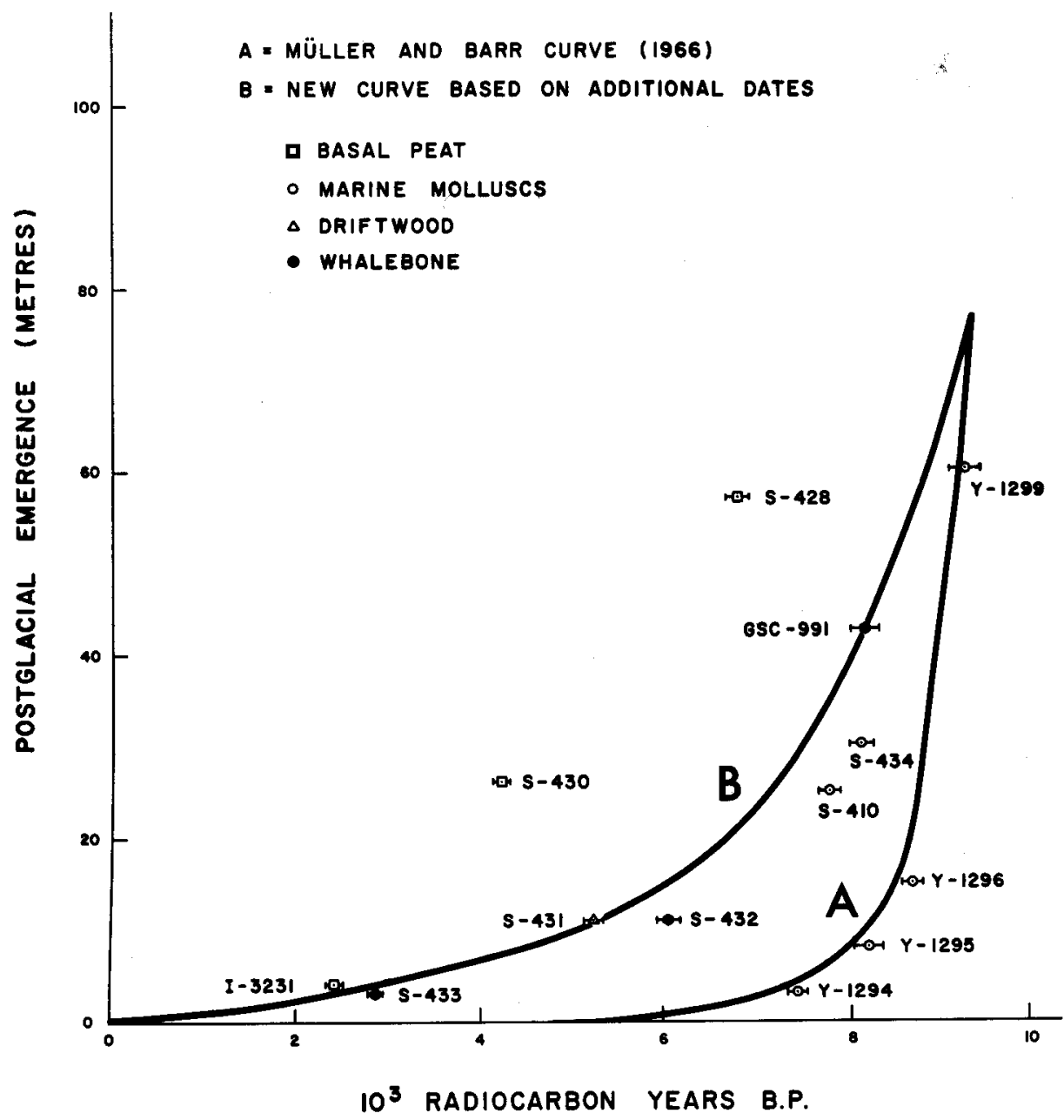

FIG. 5. Curves of postglacial emergence for the Truelove Inlet area. Curve $A$ is the original Müller and Barr curve, based entirely on marine molluscs; $B$ is the new curve based on more reliable materials such as whalebone and driftwood.

emergence can be corroborated by a date from a different type of material (S-433: whalebone), is all the more valuable.

Since in the field area lakes lie at nearly all levels from sea level almost to the marine limit, studies of the type undertaken by Hyvärinen (1968, 1969), Häggblom (1963), and Govorukha et al. (1965), involving analysis of the diatom flora to establish the transition from marine to freshwater sediments, might appear to provide a useful and accurate technique in tracing the progress of emergence. Such a study has not been undertaken, but it might well be a useful one to pursue in the future. One possible disadvantage in the field area is the shallowness of the lakes. Many of them freeze to the bottom, and the lake beds display well-developed patterned ground, indicative of a mixing of the sediments, to the point where the 
transition from marine to freshwater sediments would probably be quite unrecognizable.

The elevations of all the samples were determined by levelling from present sea level. The datum used until break-up was the surface of the sea-ice in tidal lagoons, where the ice is undisturbed by pressure. After break-up, the highest level of seaweed and other flotsam, at or a little above high-water mark was used.

Some tidal data are available for the Base Camp lowland area. They were collected by Spencer Appolonio, leader of the Arctic Institute's Devon Island Expedition, 1961-63, and are available from the Arctic Institute of North America. Hourly readings were recorded from 29 May until 25 June 1961. During this period, both spring and neap tides were recorded. Tidal range at high spring tide was $3.28 \mathrm{~m}$.; tidal range at low neap tide was $0.8 \mathrm{~m}$; and mean tidal range was $2.06 \mathrm{~m}$. Mean sea level, as established on the basis of these very limited data, is $1.64 \mathrm{~m}$. below extreme high-water mark, hence $1.64 \mathrm{~m}$. below the reference datum on which all the elevations of samples are based. While a mean sea level based on only one month's observations is not sufficiently valid to use as the basis for establishing elevations, it at least gives some measure of the amount which should be added to make these data reasonably comparable with those from areas where an accurate determination of mean sea level is used as the reference datum.

\section{CURVES OF POSTGLACIAL EMERGENCE AND UPLIFT}

Radiocarbon dating of the various types of organic material collected, from as wide an altitudinal range as possible, forms the basis for the construction of an emergence curve (Fig. 5). All dates are given in radiocarbon years rather than calendar years; since, as Andrews has pointed out $(1970 \mathrm{~b}, \mathrm{p}$. 27) all the work on discrepancies in this area has so far dealt with terrestrial materials, no attempt has been made at adjusting the dates from material from the field area, since it is largely marine. Of the samples used for the construction of the curve, 3 are whalebone, 1 is driftwood, 1 is basal peat, and only 2 are marine shells. The new curve is considered to be more reliable than that published in the earlier paper (Müller and Barr 1966) and reproduced here for comparison (Fig. 5). Fig. 2 indicates the locations of the collection sites of all the samples referred to, and Table 1 supplies the relevant data on the samples used in the construction of the emergence curve.

Five dated samples, S-412, S-413, Y-1297, Y-1733 and Y-1734 (Nos. 14 to 18 in Table 1) have not been plotted on Figs. 5 and 6, since it was felt that they do not contribute significantly to the picture of postglacial emergence. Some (Y-1733 and Y-1734) are interstadial, while most of the rest appear to have died at some depth.

Some discrepancies in the radiocarbon ages of certain samples (e.g. Y-1299) between the two papers will be apparent. These arise from the decision as to whether or not a correction should be made for radiocarbon deficiencies in arctic marine material. In the earlier paper (Müller and Barr 1966, p. 265) a reduction of 500 years was made at the suggestion of Minze Stuiver, on the basis of his work in East Greenland where it was found that present-day shells from near Mesters 


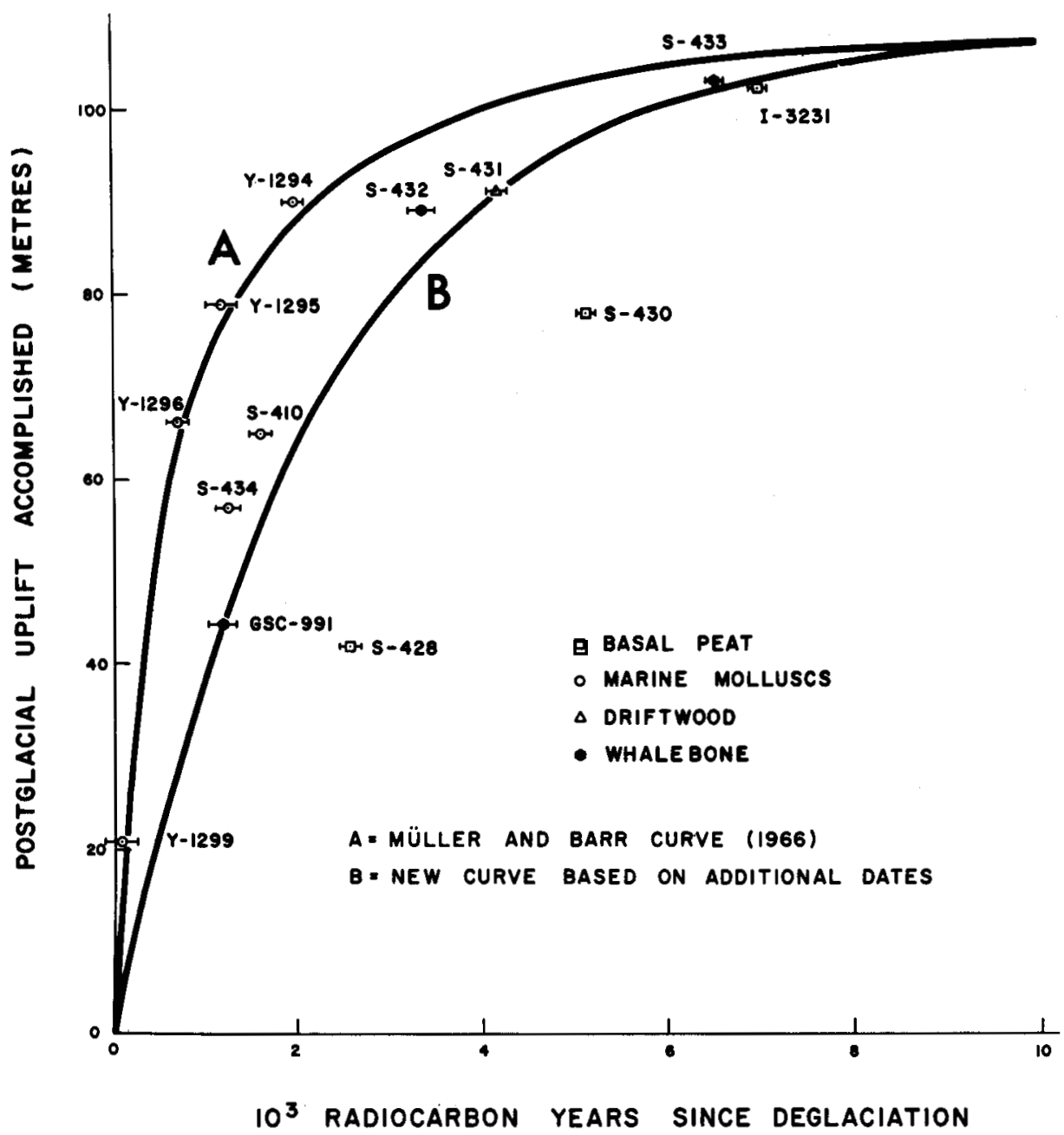

FIG. 6. Curves of postglacial uplift for the Truelove Inlet area. $\mathbf{A}$ is the original Muiller and Barr curve; $B$ is the new curve.

Vig dated to 550 B.P. (Washburn and Stuiver 1962). Assuming that a correction should be made for marine organic material, the problem is compounded when dealing with a mobile species such as the Greenland whale, in that the correction required should theoretically increase with latitude (Stuiver, personal communication, 1968), and also would be affected by upwelling of deep old water in certain areas (Blake, personal communication, 1970; Andrews 1970b, p. 27). Thus the correction involved would depend on the migration routes and the feeding habits of the whale. This poses enough problems with the present Greenland whale population, but the problems are greatly increased, when attempting an evaluation of sample GSC-991, with respect to its migrations more than 8,000 years ago. Moreover, Wallace Broecker (personal communication, 1968) has suggested that no correction for ${ }^{14} \mathrm{C}$ deficiency in GSC-991 is necessary. Weston Blake Jr. has 
also indicated (personal communication, 1968) that all marine dates should be accepted without correction, on the premise that it is better to present uncorrected dates than to apply a correction that may be inaccurate. Hence, until a date for modern marine shells and whalebone becomes available from Jones Sound, the writer has decided to adopt the latter course, and to make no correction for ${ }^{14} \mathrm{C}$ deficiencies in marine organisms. This also applies to the shell samples on which the original Müller and Barr curve was based, hence the discrepancies in those dates between the two papers.

To produce uplift curves (Fig. 6) from the emergence curves, a correction was made for eustatic sea level rise during the period under consideration. The corrections made were based on the curve of postglacial eustatic sea level rise published by Shepard and Curray (1967) from some of the more stable coastal areas of the world. Whereas there are many differences of opinion as to the exact details of postglacial eustatic sea level changes, particularly during the last 6,000 years (see for example Fairbridge 1961, 1967; Bloch 1965; Graul 1960), these differences are probably due to variations in isostatic depression of coastal areas by the weight of the transgressing sea, depending on variations in coastal configuration and off-shore bathymetry (Bloom 1967). In any case, these differences do not influence the final result, as expressed in the uplift curve of the Truelove Inlet area, to any significant extent, and they are not considered further. The curve published by Shepard and Curray (1967) was chosen in preference to the others as being representative of several stable coastal areas, all of which show a high degree of agreement.

The control on the form of the emergence and uplift curves (Fig. 5 and 6) is much closer than on the earlier curves, which were based entirely on marine mollusc dates. Thus, for example, in the most recent part of the emergence curve, it is bracketed quite narrowly by two dates from different materials, but from almost identical elevations. I-3231 $(2,450 \pm 90)$, being a sample of basal peat, provides a minimum age for emergence of the site, whereas $S-433(2,900 \pm 85)$, being a sample of whalebone, provides a maximum age. A similar juxtaposition in elevation of datable materials of differing types occurs in an earlier part of the curve. Thus S-431 (5,280 \pm 100$)$, consisting of driftwood, and S-432 $(6,100 \pm$ 125), consisting of whalebone, were both collected from the same elevation. Whereas the driftwood was most probably deposited at extreme high water mark, thus providing a minimum age for emergence, the whale is likely to have stranded in the intertidal zone, or even at slightly greater depth, thus providing a maximum age for emergence. That there should be some difference in the age of these two samples should, therefore, be expected, and indeed the two samples corroborate each other. For these reasons, apart from the inherent greater reliability of the dated materials, greater confidence can be placed in this newly constructed curve than in the earlier Müller and Barr (1966) curve.

The marine limit in the Truelove Inlet area, originally reported as $65 \mathrm{~m}$., has now as a result of further field-work been established to lie at approximately $76 \mathrm{~m}$. on the evidence of highest strandlines and lowest perched blocks (R. H. King 1969, p. 116). It is clear that the date of 9,360 B.P. for sample Y-1299 represents a minimum date for deglaciation. Extrapolation from the emergence 
curve, with this in mind, would indicate a date of approximately 9,450 B.P. for the marine limit, and this is assumed to be synchronous with deglaciation. Total uplift since that date has thus been $107 \mathrm{~m}$. (Fig. 6).

Fig. 6, which combines for comparative purposes the original 1966 uplift curve and the new uplift curve, indicates that the maximum rate of postglacial uplift was considerably less rapid than was earlier thought. Thus during the first thousand years following deglaciation the rate of uplift was in the order of $4.05 \mathrm{~m}$. per century, rather than the maximum rate of $6.5 \mathrm{~m}$. per century calculated earlier. All indications are that isostatic uplift is at present minimal, and is being matched by eustatic sea level rise.

A chance remark by Frederick Cook (1911), who wintered at Cape Hardy in 1909-10 on the return journey from his polar attempt, about the partial submergence of old Eskimo dwellings, has given rise to some speculation as to possible recent submergence in this area (Lethbridge 1938, p. 414; Roots 1963, p. 179). The site in question lies at the extreme eastern tip of Cape Hardy, and not on Cape Sparbo, as described by Cook. (For a discussion of the confusion in geographic nomenclature in this area, see Lowther 1962, p. 2). The structures concerned lie above the present high-water mark, and are well vegetated, indicating that they are never washed by the sea even at high spring tides. However, the relatively low elevation of these structures above sea level (less than $1 \mathrm{~m}$. above high-water mark) is indicative of the fact that isostatic uplift is now extremely slow, and that an equilibrium between uplift and eustatic sea-level rise may have been reached.

\section{POSSIBLE SOURCES OF ERROR IN THE EARLIER CURVES}

The main weakness of the earlier uplift curve was its total reliance on radiocarbon dating of marine molluscs. This is because molluscs may live and die at varying depths, so that the dates they provide may be completely unrelated to the sea level at the time of death, which would inevitably be higher by an unknown amount than the sample location. Where shells occur in situ in deltaic formations, it is in many places possible to relate them by stratigraphic correlation to a specific sea level at a higher elevation (cf. Løken 1965; C. A. M. King 1969, p. 209), but this was not possible on Devon Island, where all the marine mollusc samples were collected from the surface.

Without such stratigraphic correlations, attempts at relating certain species of molluscs to a particular depth zone tend to be rather unreliable. It is generally accepted that Mytilus edulis, the common blue mussel, gives a reasonably accurate indication of its contemporary sea level in that it is invariably a shallow water species most abundant in the intertidal zone (Craig 1969, p. 75; Olsson and Blake 1962, p. 12; Webber et al. 1970, p. 322); unfortunately, however, this species is not found, either living or fossil, as far north as Jones Sound. With regard to the commonest fossil species (Mya truncata, Hiatella arctica, Serripes groenlandicus and Macoma calcarea) in the raised marine deposits of northern Devon Island, the paper by McAlester and Rhoads (1967) appears at first to be pertinent. They pointed out that bivalves such as Mya, Macoma and Hiatella, which 
are adapted to deep vertical burrowing in sands and silts, are common only in intertidal and very shallow subtidal sediments. They relate this preference to protection from environmental stresses, particularly temperature and salinity fluctuations, desiccation, and danger from terrestrial predators. From this, one might assume that large numbers of these bivalves at any particular level, might be reasonably indicative of the approximate location of their contemporary sea level, and thus should provide useful material for the dating of emergence.

Study of the available data on depths of occurrence of these molluscs at present, however, leads one to doubt the above assumptions. In a paper on the marine invertebrates at Point Barrow, MacGinitie (1955) pointed out that Hiatella arctica was most numerous at depths greater than $34 \mathrm{~m}$., and that Mya truncata was collected from depths ranging from $37 \mathrm{~m}$. to $147 \mathrm{~m}$. In a recent study of the fauna of Hudson Bay, Wagner (1969) pointed out that Mya truncata was not collected from depths greater than $100 \mathrm{~m}$., and was most common at the shallow end of its range, i.e. $35 \mathrm{~m}$. to $50 \mathrm{~m}$. Hiatella arctica was collected only between $35 \mathrm{~m}$. and $165 \mathrm{~m}$., with its optimum depth between $35 \mathrm{~m}$. and $60 \mathrm{~m}$. Optimum depths for Macoma calcarea were between $165 \mathrm{~m}$. and $235 \mathrm{~m}$.

It is evident from these studies that in all probability the marine molluscs collected in the Truelove Inlet area had lived and died within quite a considerable depth range. Those shells collected from raised beach ridges may have been washed out from the original sediments that contained them, and have become incorporated in the raised beach materials by wave action as the sea retreated across the lowland. Thus the dates obtained for such samples would in no way be related to their contemporary sea levels, which must have been higher by an unknown amount when the molluscs died. The excessively steep uplift curve published by Müller and Barr (1966) is thus in error, since the above possibility was not taken into consideration.

\section{INTERSTADIAL SHELLS}

One anomalous feature of the original group of marine mollusc dates was that two dates (Y-1297 and $Y-1298 ; 16,000 \pm 240$ and 13,620 \pm 200 B.P. respectively, both uncorrected for ${ }^{14} \mathrm{C}$ deficiency in arctic marine organisms) were considerably older than a sample collected from a higher elevation (Y-1299; 9,360 \pm 160 B.P., incorrectly listed as Y-1279 in Müller and Barr 1966, Table 1). While it was recognized (Miller and Barr 1966, p. 266) that these anomalously great ages might be due to errors in laboratory analysis, in the numbering of samples, or to the inclusion of old, i.e. interstadial or interglacial shells, it was postulated that these shells might date from a period of restrained rebound related to the initial thinning of the ice in late-glacial time. This hypothesis was largely prompted by the fact that when an acceptable correction for eustatic sea level rise was made to all the radiocarbon dates, the resultant curve bore a marked resemblance to a restrained rebound curve (see, for example, Tanner 1965; Einarsson 1966; Andrews 1969, 1970b, p. 13). As Andrews has pointed out (e.g. 1969, p. 50), isostatic rebound begins from the time that the ice mass begins to thin and retreat. This restrained rebound continues until the area becomes 
practically clear of ice, when the phase of restrained rebound passes smoothly into the much more rapid free postglacial rebound. The hypothesis by Müller and Barr (1966) would have involved at least the eastern part of Jones Sound, including what is now the Truelove Inlet area, being free of ice, but still so close to the ice-margin as to be isostatically under the influence of the Devon Island ice mass, resulting in a restrained rebound effect, even though the area was ice-free. It was felt that in this area, the radiocarbon dates provided direct evidence of restrained rebound, normally unobtainable owing to the continued presence of ice ruling out the possibility of the deposition of datable organic material.

As the result of further field-work, however, evidence came to light which necessitates a reappraisal of the above hypothesis: 2 marine mollusc samples dating from the period 30,000 to 35,000 years B.P. were collected. The details of these samples are included in Table 1 (Y-1733 and Y-1734; 30,100 \pm 1500 and 31,200 \pm 1800 respectively). The occurrence of shell samples of comparable and even greater ages in the Canadian Arctic and in Svalbard is not a new discovery (cf. Sim 1961; Olsson and Blake 1962; Blake 1964, 1966; Løken 1966; C. A. M. King 1969; Mercer 1970; Andrews 1970b, p. 19). As Bird (1967, p. 137) has suggested, the majority of these "old" shells probably lived during an interstadial some 30,000 to 35,000 years ago, and were later moved on to the land by glacier ice. That many of the shells are still intact, and often indistinguishable from much younger shells is, as Sim $(1961$, p. 122) suggested, probably due to the fact that the enclosing sediments were frozen during transport. A similar explanation has been proposed by Blake for "old" shell samples from the south coast of the Meta Incognita Peninsula, southern Baffin Island (Blake 1966, p. 6) and for similar samples from Bathurst Island (Blake 1964, p. 2).

It is suggested that an almost identical sequence of events may have occurred in northeastern Devon Island. An easterly flow of ice down Jones Sound may well have transported sea bottom deposits up onto the northwest-facing coastal lowlands in the vicinity of Cape Sparbo, Cape Skogn and Truelove Inlet. Such an ice movement is strongly suggested by Pelletier (1966) on the basis of the bathymetry of Jones Sound. He postulated a major trunk glacier flowing east down Jones Sound, and collecting tributaries from the fiords of southern Ellesmere Island (Pelletier 1966, Fig. 9). This reconstruction is further supported by Blake's (1970) recent findings in southern Ellesmere Island. He discovered that a synchronous "pumice level", dating to approximately 5,000 B.P. and readily identifiable by the occurrence of dark-brown dacitic pumice, rises westward along Jones Sound from 16.5 m.a.s.l. at the mouth of South Cape Fiord, Ellesmere Island, to $24.5 \mathrm{~m}$. at the eastern tip of Colin Archer Peninsula, Devon Island, over a distance of about $130 \mathrm{~km}$. The tilt of this shoreline, together with dates from elsewhere in the Queen Elizabeth Islands, indicates a former ice-dispersal centre somewhere in the neighbourhood of Grinnell Peninsula or Cornwall Island, with flow being easterly from that centre down Jones Sound. This major icedispersal centre, named the Innuitian Ice Sheet by Blake (1970, p. 659), extending as a ridge from southern Bathurst Island to the vicinity of Eureka, Ellesmere Island, is also indicated on the isobase maps of relative uplift during the last 8,000 and 6,000 years (Andrews 1970b, Figs. 7-8 and 7-9). 
Given the configuration of the coastal area of northern Devon Island with which this paper is concerned, an easterly flow of ice along Jones Sound could quite naturally be expected to carry material from the sea-bed up onto these northwest-facing lowlands. Reworking by wave action of the material thus derived, and the inclusion of these interstadial shells in the much younger raised beaches which developed during postglacial emergence would satisfactorily explain the anomalous dates in excess of 30,000 years. That these marine deposits, with their included shells were not removed by northward-flowing Devon Island ice during a late-glacial phase, can be explained by the fact that they would have been protected by local topographic peculiarities, together with the marine transgression.

A variation on this theme is proposed by Mercer (1970, p. 24) who cited these "old" shells as evidence in support of his hypothesis of a marine ice-sheet in the North American sector of the Arctic Ocean during a pre-Wisconsinan glaciation. Southerly ice-flow across the Canadian Arctic Archipelago could have carried the sea shells from the sea-bed to the various locations from where they have been reported, often well above the postglacial marine limit.

Admittedly, no other signs of a south-moving ice sheet have been noted from the Canadian Arctic Archipelago, but such a glacier, slow moving and cold, and carrying virtually no rock debris as it crossed the coast, would have left few erosional or depositional traces, and the evidence of its passage might well consist mainly of scattered occurrences of transported marine sediments. (Mercer 1970, p. 24).

The Devon Island material supports Mercer's argument in terms of the northerly exposure of the collection sites, favouring the idea of southerly flow just as well as the possibility of easterly-moving ice, as suggested earlier.

A further alternative explanation for these "old" shells does not require recourse to a hypothesis of transport of shell-bearing marine sediments onto land. C. A. M. King (19.69) reported the finding of in situ paired valves of Mya truncata and Hiatella arctica in fine stratified sandy clay beneath morainic material at Cape Henry Kater in eastern Baffin Island. These shells were dated at 40,900 \pm 2,000 B.P. (Y-1985), while a further sample nearby was dated at 38,100 $\pm 1,200$ B.P. (Y-1987), although it should be mentioned that King suggested that the latter sample may not have been in situ. In the same area, a third sample (Y-1986), consisting of Astarte striata, collected from surface layers of finely bedded silt, was dated at $10,210 \pm 180$ B.P. King $(1969$, p. 203$)$ interpreted this sample as representing:

a marine incursion dating from the final deglaciation of the area, while the two older samples represent shells that were alive when the ice was advancing down the fiords and before the moraines were deposited. It suggests the last glacial of the area lasted for about 24,000 years and covered the classical Wisconsin period or the middle Weichselian.

Quite possibly, the Devon Island evidence is indicative of a similar glacial history. Here, unfortunately, none of the "old" shells have been found in situ, but were collected from raised beach ridges. Hence they had probably been washed out of their original positions in the marine sediments and reworked by wave action.

Whatever the means by which these interglacial shells reached the sites from 
which they were collected, their presence in the Truelove Inlet area probably explains the anomalously old dates previously recorded by Müller and Barr (Y-1297 of $16,000 \pm 240$ B.P., and Y-1298 of 13,620 \pm 200 B.P.). It should be mentioned that both the interstadial shells and the more recent postglacial shells, belong to the same species. There appears to be a tendency for the older shells to be thicker and heavier, but this is a relative rather than absolute difference, and could scarcely be used as a technique of field differentiation. There is thus a strong possibility that samples Y-1297 and Y-1298 included by error both interstadial and postglacial shells. Radiocarbon dating of such a mixture would inevitably produce an intermediate age, completely unrelated to the ages of the raised beaches.

TABLE 2. Comparison of radiocarbon dates of marine shells from the Base Camp lowland.

\begin{tabular}{cccccc}
\hline $\begin{array}{l}\text { Sample } \\
\text { number }\end{array}$ & $\begin{array}{l}\text { nab. } \\
\text { number }\end{array}$ & Material & Location & $\begin{array}{c}\text { Elevation } \\
\text { (m.a.s.l.) }\end{array}$ & $\begin{array}{c}\text { Age } \\
\text { (radiocarbon } \\
\text { years) }\end{array}$ \\
\hline 12 & Y-1296 & $\begin{array}{l}\text { Marine shells } \\
\text { (mainly Hiatella arctica). }\end{array}$ & $\begin{array}{l}\text { Base Camp raised } \\
\text { beach. } \\
\text { Base Camp raised } \\
\text { beach. }\end{array}$ & 15.5 & $8,740 \pm 120$ \\
15 & S-412 & $\begin{array}{l}\text { Marine shells } \\
\text { (mainly Hiatella arctica). }\end{array}$ & $\begin{array}{l}\text { Fish Lake raised } \\
\text { beach. }\end{array}$ & 23.0 & $16,800 \pm 160$ \\
14 & Y-1297 & $\begin{array}{l}\text { Marine shells } \\
\text { (mainly Hiatella arctica). }\end{array}$ & $\begin{array}{l}\text { Fish Lake raised } \\
\text { Marine shells } \\
\text { (mainly Hiatella arctica). }\end{array}$ & 23.0 & $9,570 \pm 130$ \\
\hline
\end{tabular}

To test this hypothesis, further shell samples were collected by R. H. King (1969, Table 13) from two of the locations from which the original samples were collected. The results of his findings are presented here in Table 2 . It will be seen that in the second case in Table 2, the hypothesis presented above is substantiated: shells from a beach previously dated at $16,000 \pm 240$ B.P. are now found to date to only $9,570 \pm 130$ B.P. The first case is inconclusive as regards the hypothesis under consideration. A possible interpretation is that in the second case King collected a "pure" postglacial sample, but in the first case collected another mixed sample, or else happened to collect shells which had died at some depth, and were later incorporated in the raised beach. In that there are endless possible variations in the composition of mixed samples, the possible range of radiocarbon dates on marine molluscs from any one site is very great, unless extreme care is taken in the collection of the samples.

\section{COMMENTARY}

It must be realized that the uplift curve as presented (Fig. 6), may be a reflection of more than simply glacio-isostatic rebound. In all probability it represents a complex curve, in which the effects of glacio-isostasy predominate, admittedly, but in which the effects of several other contributing factors of varying orders of magnitude are concealed. 
One important factor is the water-loading effect of eustatic sea level rise (Bloom 1967; Grant 1970). The deformation produced by a load on the earth's crust affects a considerable area around the point of application of the load; in the case of Lake Bonneville, Western Utah, for example, Crittenden (1963, p. 5522) established that the line of zero deformation lay about $50 \mathrm{~km}$. beyond the limits of the former water-body. Thus, similarly, in any coastal area, the water-load applied through eustatic sea level rise will produce isostatic depression of the neighbouring land area or, in the case of an area experiencing glacio-isostatic uplift, should tend to have a dampening effect, reducing the rate of this uplift. This water-loading effect will not be constant along all coastlines, but will, as Bloom (1967) has indicated vary, depending on a number of factors, not the least of which are the configurations of the coastline and the off-shore bathymetry. These control the mean water depth in the critical area.

The shallower the mean water depth in the immediate off-shore zone, the less will be the isostatic depressive effect of the water load represented by eustatic sea level rise on the adjacent coastal area. No attempt has been made to draw isomesobaths of the south coast of Jones Sound, since the necessary detailed bathymetric data are not available. However, from personal observation, and from the few soundings available (Chart 7070, Canadian Hydrographic Service, Marine Sciences Branch; Pelletier 1966, Fig. 9), it is clear that the off-shore zone is relatively shallow; for example, the $50 \mathrm{~m}$. isobath lies approximately $15 \mathrm{~km}$. off-shore. Hence, in that only a fraction of the possible load represented by total postglacial sea level rise can have been applied close in-shore, the dampening effect on the isostatic uplift of the Truelove Inlet area will presumably have been less than on a coastline with a steeper off-shore profile. Thus, while in all probability the Truelove Inlet area has suffered a slight retardation of the rate of postglacial isostatic uplift, this retardation would have been more severe had the off-shore profile been steeper. Clearly, then, there are real dangers in comparing uplift curves for different coastal sites, without taking into consideration such factors as coastal configuration and the off-shore profile affecting the mean water depth in the immediate off-shore zone.

A probably more significant retarding effect must inevitably be exercised by the continuous presence of the Devon Island Ice Cap. The main body of the ice cap covers an area of $12,791 \mathrm{~km}$. $^{2}$, rising to a height of $1,885 \mathrm{~m}$. (Koerner 1966). From the profiles published by Hyndman (1965), based on gravity measurements, the ice would appear to be generally about $500 \mathrm{~m}$. thick, rising to $700 \mathrm{~m}$. in places. Most significantly, the ice margin lies only $17 \mathrm{~km}$. southeast of the Truelove Inlet area (Fig. 1). The ice cap has a markedly steep front, with ice depths of $150 \mathrm{~m}$. being recorded within $1 \mathrm{~km}$. of the ice margin (Hyndman 1965).

No information is available as to possible re-advances of the ice during the last 10,000 years; however, it seems reasonable to suppose that this ice cap has been at least as large as at present throughout the period since deglaciation of the Truelove Inlet area, and was probably more extensive during the early part of that period. Inevitably, an ice cap of that magnitude must still be exerting a depressive effect on the crust. Since the Truelove Inlet area is well within the zone of isostatic influence of the ice cap, the rate of uplift must have been reduced throughout 
postglacial time, and the amount of residual uplift must still be abnormally large. This, then, is a further hidden component of the uplift curve.

Finally, one should not overlook such cautionary comments as those made by Kupsch (1967, p. 184):

The failure to recognize the influence of earth movements other than glacioisostatic uplift may lead to misinterpretations, particularly where anomalous uplift conditions exist within formerly glaciated regions.

There is always the possibility of a tectonic component, possibly triggered off by glacio-isostatic movement, being concealed by glacio-isostatic rebound. Andrews (1970a) has suggested that such tectonic movements might result in rates of uplift faster or slower than expected. In this context, Biske's recent paper (1970) on the postglacial uplift of the Baltic Shield is very relevant to the structurally-similar Canadian Shield. He has pointed out that the zone of present uplift is not confined to the area of former glaciation, but extends as far as the Black Sea and the Eastern Donbass. Moreover he stressed that the Baltic Shield, as a structural unit, has been experiencing uplift since the Upper Precambrian, and that this tectonic uplift might possibly have been retarded during glacial loading, and accelerated as the ice melted (Biske 1970, p. 37). Biske would thus suggest that the postglacial uplift of the Baltic Shield is basically tectonic rather than glacio-isostatic.

It is not implied that tectonic movement is dominant in the Truelove Inlet area; it is clear from the shape of the uplift curve (and from its close resemblance to uplift curves from other formerly glaciated areas) that glacio-isostasy is the major component of the postglacial movement in the Truelove Inlet area. Nevertheless, the possibility of a contributory tectonic component cannot be ruled out.

\section{CONCLUSIONS}

The possible sources of error so notoriously present in attempts at constructing emergence and uplift curves based on ${ }^{14} \mathrm{C}$ dates of fossil marine molluscs associated with elevated marine deposits can be obviated by the use of other organic materials such as whalebone and dxiftwood; which are considered to be more reliable indicators of past sea level changes. When this was done for the Truelove Inlet area of northern Devon Island, it was found that the resultant curve of postglacial uplift was markedly less steep than that constructed earlier for the same area, but based entirely on marine molluscs (Müller and Barr 1966). The presence of marine molluscs of ages in excess of 30,000 years suggests an interstadial when the Truelove Inlet area was completely free of glacier ice, and was inundated by the sea.

Accidental mixing during collection of such interstadial shells with postglacial shells is a possible cause of the dates previously recorded of the order of 12,000 to 15,000 B.P. Hence the earlier hypothesis of fossil evidence of the onset of restrained rebound, based upon these dates (Müller and Barr 1966, Fig. 3 and p. 267 ) is probably invalid in this particular case. This does not rule out the possibility of such evidence being found under suitable conditions in other localities, as for example in the situation reported by L $\phi \mathrm{ken}$ (1966) at Cape Aston, Baffin Island (Andrews 1970b, p. 133). 
While the form of the uplift curve, and its similarity to all other uplift curves from the formerly glaciated areas of the Canadian Arctic indicate that glacioisostasy is the major component of the observed postglacial uplift, the possibility of tectonic movements, either delaying or accelerating uplift, should not be overlooked. The rate of uplift throughout postglacial time has probably been reduced due to the isostatic depressive effect of eustatic sea level rise and, more significantly, to the continued presence of the Devon Island Ice Cap.

\section{ACKNOWLEDGEMENTS}

The field work on which this paper is based was undertaken from the Arctic Institute of North America's Base Camp during the 1966 and 1967 field seasons. The Arctic Institute also provided invaluable financial and logistical support. I am particularly grateful to Mr. Kenneth De la Barre, Director of the Montreal office of the Institute. Logistical support was generously made available by Dr. E. F. Roots of the Polar Continental Shelf Project. I also wish to thank Mr. Hugh Lloyd and Mr. Ward Elcock for their untiring work as field-assistants, often under unpleasant conditions. The radiocarbon analyses were generously undertaken by the Geological Survey of Canada Radiocarbon Laboratory, Yale University Radiocarbon Laboratory, and the University of Saskatchewan Radiocarbon Laboratory. The driftwood sample was identified by R. J. Mott of the Geological Survey of Canada, and the whalebone from a photograph, by Dr. R. Lawes, Cambridge University. The manuscript was critically reviewed by Dr. Weston Blake Jr., Geological Survey of Canada; Dr. Fritz Müller, Universität Zürich; Dr. Walter Kupsch, University of Saskatchewan; and Dr. James Gardner, University of Iowa; their comments and suggestions were invaluable, and many of them have been incorporated in the text.

\section{REFERENCES}

ANDREwS, J. T. 1969. The pattern and interpretation of restrained, postglacial and residual rebound in the area of Hudson Bay. Proceedings of the Earth Science Symposium on Hudson Bay, Ottawa, February 1968. Geological Survey of Canada Paper, 68-53: 49-62.

1970a. Present and postglacial rates of uplift for glaciated northern and eastern North America derived from postglacial uplift curves. Canadian Journal of Earth Sciences, 7(2): 703-15.

1970b. A geomorphological study of post-glacial uplift with particular reference to Arctic Canada. London: Institute of British Geographers. $156 \mathrm{pp}$.

BIRD, J. B. 1967. The physiography of Arctic Canada. Baltimore: Johns Hopkins Press. $336 \mathrm{pp}$.

BISKE, G. S. 1970. O prirode poslelednikogo podnatiya Baltiyskogo Shchita. Izvestiya Bsesoyuznogo Geograficheskogo Obshchestva, 102(1): 34-39.

BLAKE, W. JR. 1961. Radiocarbon dating of raised beaches in Nordaustlandet, Spitsbergen. In: G. O. Raasch, ed. Geology of the Arctic. Toronto: University of Toronto Press. pp. 133-45.

1964. Preliminary account of the glacial history of Bathurst Island, Arctic Archipelago. Geological Survey of Canada Paper, 64-30, 8 pp.

1966. End moraines and deglaciation chronology in Northern Canada, with special reference to Southern Baffin Island. Geological Survey of Canada Paper, 66-26, $31 \mathrm{pp}$.

1970. Studies of glacial history in Arctic Canada, I. Pumice, radiocarbon dates and differential postglacial uplift in the eastern Queen Elizabeth Islands. Canadian Journal of Earth Sciences, 7(2): 634-64. 
BLOCH, M. R. 1965. A hypothesis for the change of ocean levels depending on the albedo of the polar ice caps. Palaeogeography, Palaeoclimatology, Palaeoecology, 1: 127-42.

BLOOM, A. L. 1967. Pleistocene shorelines: a new test of isostasy. Bulletin of the Geological Society of America, 8(12): 1477-94.

Cook, F. A. 1911. My attainment of the Pole. New York and London: Mitchell Kennerley. $604 \mathrm{pp}$.

CRAIG, B. G. 1969. Late-glacial and postglacial history of the Hudson Bay region. Proceedings of the Earth Science Symposium on Hudson Bay, Ottawa, February 1968. Geological Survey of Canada Paper, 68-53: 63-77.

CRITTENDEN, M. D. 1963. Effective viscosity of the earth derived from isostatic loading of Pleistocene Lake Bonneville. Journal of Geophysical Research, 68(19): 5517-30.

DUdoK VAN heel, W. H. 1962. Sound and Cetacea. Netherlands Journal of Sea Research, 1(4): 407-507.

1966. Navigation in cetaceans. In: K. S. Norris, ed. Whales, dolphins, and porpoises. University of California Press. pp. 597-606.

EINARSSON, T. 1966. Late and postglacial rise in Iceland and subcrustal viscosity, Jökull, 16(3): 157-66.

FAIRBridge, R. W. 1961. Eustatic changes in sea level. Physics and Chemistry of the Earth. New York: Pergamon Press. 4: 99-185.

1967. Coral reefs of the Australian region. Landform Studies from Australia and New Guinea. J. N. Jennings and J. A. Mabbutt, eds. Cambridge University Press. pp. 386-418.

GOVORUKHA, L. S., L. M. SAUER and A. S. ZELENKo. 1965. Palaeogeographical reconstruction of Franz Josef Land during the Holocene by the investigation of lacustrine deposits. Trudi Nauchno-Issledobatelskogo Instituta Geologii Arktiki, 143: 319-26. (Russian with English summary.)

GRANT, D. R. 1970. Recent coastal submergence of the Maritime Provinces, Canada. Canadian Journal of Earth Sciences, 7(2): 676-89.

GRAUL, H. 1960. Der Verlauf des glazialeustatischen Meeresspiegelanstieges berechnet an Hand von C-14 Datierungen. Verhandlungen des Deutschen Geographentages. Deutscher Geographentag, Berlin, 1959, Tagungsbericht und wissenschaftliche Abhandlungen, 32: $232-42$.

HäGGBLOM, A. A. 1963. Sjöar på Spetsbergens Nordostland. Ymer, 1-2: 76-105.

HYNDMAN, R. D. 1965. Gravity measurements on the Devon Island ice cap, and an adjoining glacier. Journal of Glaciology, 5(40): 489-96.

HYVÄRINEN, H. 1968. Late-Quaternary sediment cores from lakes on Bjørnøya. Geografiska Annaler, 50A(4): 235-47.

1969. Trullvatnet: a Flandrian stratigraphical site near Murchisonfjorden, Nordaustlandet, Spitsbergen. Geografiska Annaler, 51A(1-2): 42-45.

KING, C. A. M. 1969. Glacial geomorphology and chronology of Henry Kater Peninsula, East Baffin Island. Arctic and Alpine Research, 1(3): 195-212.

KING, R. H. 1969. Periglaciation on Devon Island, N.W.T. Unpublished Ph.D. Thesis, University of Saskatchewan. $470 \mathrm{pp}$.

KOERNER, R. M. 1966. Accumulation on the Devon Island ice cap, Northwest Territories, Canada. Journal of Glaciology, 6(45): 382-92.

KUPSCH, w. O. 1967. Postglacial uplift - a review. In: W. J. Meyer-Oakes, ed. Life, land and water. Winnipeg: University of Manitoba Press. pp. 155-85. 
LETHBRIDGE, T. C. 1938. Eskimo archaeology. (Appendix to "An expedition to North West Greenland and the Canadian Arctic in 1937" by J. M. Wordie.) Geographical Journal, 92: 412-15.

LøKEN, o. H. 1965. Postglacial emergence at the south end of Inugsuin Fiord, Baffin Island, N.W.T. Geographical Bulletin, 7(3-4): 243-58.

1966. Baffin Island refugia older than 54,000 years. Science, 153: 1378-80.

LOWTHER, G. R. 1962. An account of an archaeological site on Cape Sparbo, Devon Island. National Museum of Canada Bulletin, 180: 1-19.

MCALESTER, A. L. and D. C. RHOADS. 1967. Bivalves as bathymetric indicators. Marine Geology, 5(5/6): 383-88.

MACGINITIE, G. E. 1955. Distribution and ecology of the marine invertebrates of Point Barrow, Alaska. Smithsonian Miscellaneous Collection, 128(9). 201 pp.

MERCer, J. H. 1970. A former ice sheet in the Arctic Ocean? Palaeogeography, Palaeoclimatology, Palaeoecology, 8: 19-27.

MÜLLER, F. and W. BARR. 1966. Postglacial isostatic movement in northeastern Devon Island, Canadian Arctic Archipelago. Arctic, 19(3): 263-69.

OLSSON, I. U. and W. BLAKE JR. 1962. Problems of radiocarbon dating of raised beaches, based on experience in Spitsbergen. Norsk Geografisk Tidsskrift, 18: 47-64.

PELLETIER, B. R. 1966. Development of submarine physiography in the Canadian Arctic and its relation to crustal movements. In: G. D. Garland, ed. Continental Drift. Royal Society of Canada Special Publication, 9: 77-101.

RAY, C. 1961. A question in whale behaviour. Natural History, 70(46).

Roots, E. F. 1963. Physiography (Devon Island), Geological Survey of Canada Memoir, No. 320 (Geology of the north-central part of the Arctic Archipelago, Northwest Territories; Operation Franklin). pp. 164-79.

SHEPARD, F. P. and J. R. CURRAY. 1967. Carbon-14 determination of sea level changes in stable areas. In: Progress in oceanography, Vol. 4, The Quaternary history of the ocean basins. New York: Pergamon Press. pp. 283-91.

SIM, v. w. 1961. A note on high-level marine shells on Fosheim Peninsula, Ellesmere Island, N.W.T. Geographical Bulletin, 16: 120-23.

TANNER, W. F. 1965. Cause and development of an Ice Age. Journal of Geology, 73(3): 413-30.

WAGNer, F. J. E. 1969. Faunal study, Hudson Bay and Tyrrell Sea. Proceedings of the Earth Science Symposium on Hudson Bay, Ottawa, February 1968. Geological Survey of Canada Paper, 68-53: 7-48.

WASHBURN, A. L. and M. STUIVER. 1962 . Radiocarbon-dated postglacial delevelling in Northeast Greenland and its implications. Arctic, Vol. 15(1): 66-73.

WEBBER, P. J., J. W. RICHARDSON and J. T. ANDREWs. 1970. Postglacial uplift and substrate age at Cape Henrietta Maria southeastern Hudson Bay, Canada. Canadian Journal of Earth Sciences, 7(2): 317-25. 